\title{
Carbon Monoxide and Particulate Matter Concentrations inside the Road Tunnels of Guanajuato City, Mexico
}

\author{
Adrián Zamorategui-Molina ${ }^{1 *}$, Norma L. Gutiérrez-Ortega ${ }^{1}$, \\ Juan Carlos Baltazar-Vera ${ }^{2}$, Julio Del Ángel-Soto ${ }^{3}$, David Tirado-Torres ${ }^{1}$ \\ ${ }^{1}$ Department of Civil and Environmental Engineering, University of Guanajuato, 36000 \\ Guanajuato, Mexico \\ ${ }^{2}$ Department of Mine Engineering, Metallurgy and Geology, University of Guanajuato, 36000 \\ Guanajuato, Mexico \\ ${ }^{3}$ Department of Chemical Engineering, University of Guanajuato, 36050 Guanajuato, Mexico
}

\begin{abstract}
In the city of Guanajuato, Mexico, road tunnels offer drivers an effective means of avoiding traffic congestion. Additionally, they enable pedestrians to reduce their travel time and distance. However, exposure to elevated levels of carbon monoxide (CO) and particulate matter (PM), including $\mathrm{PM}_{2.5}$ and $\mathrm{PM}_{10}$ consisting of vehicle-emitted particles and resuspended dust, poses risks to human health. Hence, we monitored the $\mathrm{CO}, \mathrm{PM}_{2.5}$, and $\mathrm{PM}_{10}$ concentrations; wind speed; and number of vehicles in three popular tunnels among pedestrians, all of which exhibited relatively high levels of pollution, in Guanajuato. We evaluated the $\mathrm{CO}$ concentration using a portable non-dispersive infrared radiation (NDIR) sensor (ALTAIR Pro Single-Gas Detector) and the PM2.5 and $\mathrm{PM}_{10}$ concentrations using a handheld mass monitor equipped with a high-precision laser sensor (Aerocet 831). We then employed X-ray diffraction (XRD), X-ray fluorescence (XRF), and scanning electron microscopy-energy dispersive X-ray spectroscopy (SEM-EDS) to analyze the mineralogy, chemical composition, and morphology of the PM, respectively. Although the average $\mathrm{CO}$ concentration fell below the World Health Organization (WHO)'s guideline of $50 \mathrm{ppm}$ for a 30-minute exposure, the average $\mathrm{PM}_{10}$ concentration exceeded the guideline of $50 \mu \mathrm{g} \mathrm{m}^{-3}$ for a 24-hour exposure inside all three tunnels. The high emission factors we found demonstrate the necessity of installing ventilation systems in these passageways. Lastly, the chemical components of the PM corresponded to the mineral dust originating from the eroded rock (mainly rhyolite), soil, and fortifying construction material inside the tunnels.
\end{abstract}

Revised: June 21, 2021

Accepted: June 23, 2021

${ }^{*}$ Corresponding Author:

Keywords: CO, Emissions factors, $\mathrm{PM}_{2.5}$, Underground road

\section{INTRODUCTION}

Publisher:

Taiwan Association for Aerosol Research

ISSN: $1680-8584$ print

ISSN: 2071-1409 online

Copyright: The Author(s). This is an open access article distributed under the terms of the Creative Commons Attribution License (CC BY 4.0), which permits unrestricted use, distribution, and reproduction in any medium, provided the original author and source are cited.

The oldest tunnels excavated in Egypt in the year 1500 B.C. and Jerusalem in the year 700 B.C. were built for water conduction. Later, the Romans carried out the construction of aqueducts for the expansion of their cities and were the first to open road tunnels when they built roads (EI Salam, 2002; Priego, 2010). The road tunnels favored the continuous and safe passage of vehicles, through topographic obstacles (mountains), permitting shorter distances between two points with a minimum slope, thus reducing the travel time, energy, as well as the reduction of combustion gases to the atmosphere. Road tunnels have been built in crowded cities to solve many traffic problems and are designed to be safe and comfortable for human usage. However, the number of vehicles passing through a tunnel contributes to higher concentrations of pollution and drivers can be exposed to the toxic carbon monoxide ( $\mathrm{CO}$ ), inhalable particulate matter $\mathrm{PM}_{10}$ ) and fine particulate matter $\left(\mathrm{PM}_{2.5}\right)$, particles $(<10 \mu \mathrm{m}$ and $<2.5 \mu \mathrm{m}$ in aerodynamic diameter, respectively 
(Sanchez-Ccoyllo et al., 2009; Perez-Martínez, 2014).

Guanajuato, considered as a medium-sized, colonial city, is located in a hilly terrain of central Mexico at about 2000 meters above sea level, settled on the so-called "Guanajuato conglomerate" consisting mainly of rhyolite which is composed of $20 \%$ quartz and $30 \%$ alkaline feldspar. It also contains smaller amounts of biotite $\left[\mathrm{K}(\mathrm{Mg}, \mathrm{Fe})_{3} \mathrm{AlSi}_{3} \mathrm{O}_{10}(\mathrm{OH}, \mathrm{F})_{2}\right]$ and plagioclase $\left[(\mathrm{Na}, \mathrm{Ca})(\mathrm{Si}, \mathrm{Al})_{3} \mathrm{O}_{8}\right]$, as well as lead (PbS) and iron sulfides (FeS) disseminated in its conglomerate (Lepe and Loza, 2016). Its principal economic activities are silver/gold mining and tourism (Puy-Alquiza et al., 2016). The main tunnels developed in the city were originally built in the colonial era when the Guanajuato River was contained in order to avoid recurrent floods. The Meson de San Antonio was the first vaulted structure to be developed above the river channel. Later, in 1961, the project to install pipes below the river in order to drain it began, giving rise to the well-known Calle Subterranea or Calle Miguel Hidalgo in the city of Guanajuato, inaugurated in 1964 (Blanco, 2011; Woitrin-Bibot et al., 2015). Currently, most of the underground streets are distributed in a network of 23 single-lane tunnels, a total of approximately 18 kilometers, through which approximately 75,000 vehicles circulate (Carreón, 2007; INEGI, 2015; Woitrin, 2015).

However, single-lane tunnels are not enough for the growing number of cars causing road traffic to move slowly, and also causing congestion within the tunnels during rush hours. This situation spurs pedestrians to walk through the tunnels, reducing the time it takes to get to their destinations. In this way, pedestrians are more in contact with the pollutants accumulated inside the tunnel, breathing $\mathrm{CO}$, particulate matter (PM), $\mathrm{NO}_{2}$, volatile organic compounds, among others, which can cause health problems (Brugge et al., 2007; Park et al., 2018).

For the adequate operation of road tunnels, the World Road Association (PIARC) establishes two scenarios for the implementation of a ventilation system. The first considers maintaining the indoor air quality (IAQ) and the second considers the case in which a fire risk is generated inside the tunnel. The air quality inside the tunnel depends on the number of vehicles and the traffic congestion. IAQ is based on keeping the concentration of $\mathrm{CO}, \mathrm{PM}$ and more recently nitrogen oxides $\left(\mathrm{NO}_{x}\right.$ ) within set guidelines to protect human health (Zhou et al., 2014; Li et al., 2015; Šulc et al., 2017; PIARC, 2019). The PIARC proposes a rule for which no mechanical ventilation at all is required and the maximum tunnel length without artificial ventilation depends on the intensity of the traffic, but also depends on meteorological variables and the geography (PIARC, 2004). The following rule is adequate for natural ventilation in road tunnels with a length greater than or equal to 400 meters (Hun, 2016):

$L=C / M$

where $L$ is the permissible length in kilometers of a naturally ventilated tunnel, $C$ is a constant whose value is between 250 and 400 for bidirectional tunnels and 400 for unidirectional tunnels, and $\mathrm{M}$ is the intensity of traffic of vehicles per hour (vehicles $\mathrm{h}^{-1}$ ) that cross the tunnel.

International agencies have established guidelines relating to acceptable standards of key air pollutants that affect human health inside road tunnels. The guidelines state that the concentration of $\mathrm{CO}$ averaged over one 15-minute period should not exceed 87 parts per million (ppm; $60 \mathrm{mg} \mathrm{m}^{-3}$ ). For the particulate matter, a limit of $50 \mathrm{~g} \mathrm{~m} \mathrm{~m}^{-3}$ and $25 \mu \mathrm{g} \mathrm{m}^{-3}$ for a 24-hour period was established for $\mathrm{PM}_{10}$ and $\mathrm{PM}_{2.5}$ respectively (Longley et al., 2010; U.S. EPA, 2021), and for the $\mathrm{NO}_{2}$, a limit of 1 ppm for a 15-minute period of exposure was established (PIARC, 2019; NIOSH, 2020).

The pedestrian transit through the tunnels lasts a few minutes and the emissions of pollutants such as CO and PM depend on engine operation, fuel used, and efficiency of the combustion. As reported, based on the type of fuel used, the energy efficiency of a gasoline vehicle is about $14 \%$ in comparison with 18\% of a diesel vehicle (El-Kassaby, 2016; Hacar et al., 2016; Anenberg et al., 2017). In fact, due to the incomplete combustion, vehicles are responsible for $87 \%$ of $\mathrm{CO}$ emissions (Hall et al., 2020; Nagendra, 2021).

The monitoring of pollutant concentration inside road tunnels is the most popular method to study the inside air quality and evaluate the emission factors (EFs) because pollutants emitted by the exhaust of vehicles and those generated by the wear and tear of the engine, tires combined with the resuspension of particles, are concentrated inside of the tunnel (Handler et al., 2008; Cui, 2016; Li et al., 2017). Since the EFs are related to the mass of the pollutant emitted per distance traveled by the vehicle, the monitoring of pollutant concentrations inside the tunnels 
provides more accurate information to determine the EFs because it represents the average urban traffic (Zhao et al., 2018b).

Some authors have used tracers such as copper to determine the emission of particles by brake wear. $\mathrm{Zn}$ was used for tire wear and $\mathrm{Al}, \mathrm{Si}, \mathrm{Fe}, \mathrm{Ca}, \mathrm{K}$ were related to the resuspension of particles depending on the type of rock or material of tunnel construction (Gustafsson and Johansson, 2012). It has been reported that the emission of PM is higher in diesel vehicles than that generated by gasoline vehicles and the opposite was found with respect to the emission of $\mathrm{CO}$, observing that gasoline vehicles emit more $\mathrm{CO}$ than generated by the diesel vehicles (Sawyer et al., 2000; Pant and Harrison, 2013; Pérez-Martínez, 2014). The CO is produced by the incomplete combustion of fuel in the engine of the vehicles, and it is not detectable by humans. Once inhaled, it reacts with hemoglobin to form carboxyhemoglobin $(\mathrm{COHb})$ by displacing oxygen present in the blood and inducing intoxication. Exposures to low concentrations of $\mathrm{CO}$ occur in the large city centers compared with higher concentrations found inside road tunnels where the pollutants are pushed in the direction of air flow caused by the piston effect. This effect is generated by the movement of vehicles and the unidirectional air flow caused by the meteorological conditions that help natural ventilation (Bleecker, 2015; Zhao et al., 2018a). The objective of this investigation is to determine the variation of $\mathrm{CO}$ and PM concentration inside three of the most polluted and important road tunnels of the city of Guanajuato, Mexico.

\section{METHODS}

The city of Guanajuato, located 2000 meters above sea level, has the geographical coordinates of $21^{\circ} 1^{\prime} \mathrm{N}, 101^{\circ} 16^{\prime} \mathrm{W}$, and because of its topography the streets are steep and winding. Thus, several interconnected tunnels improve the circulation and reduce the vehicular congestion in the city. In order to determine the concentration of CO and PM in the underground tunnels of Guanajuato, the eight tunnels most used by pedestrians were studied (Galereña, Barretero, Los Ángeles, Ponciano Aguilar, Santa Fé, Tiburcio Álvarez, Calle Miguel Hidalgo and Tamazuca) (Fig. 1). The tunnels studied have positive slopes with the exception of Ponciano Aguilar that has a positive or negative slope as the topography of the city changes (Table 1). The tunnels are subject to one-way traffic except for the Tamazuca tunnel that is two-way traffic. None of the tunnels have mechanical ventilation.

Based on the higher concentrations of $\mathrm{CO}$ and because these three tunnels have the highest traffic congestion (Table 2) and higher slopes (Table 1), Galereña (GA), Barretero (BA) and Los Ángeles (LA) were selected to monitor the behavior of the pollutants. The monitoring of the pollutant concentration was made during the time it takes a person to go through the tunnel (Table 1). This and other variables were recorded every 60 meters. The study was conducted in October 2019, all seven days of the week but not consecutively, at a time between 13:00 and 14:00. This hour corresponds to lunchtime and the time when school hours end. The number of vehicles and pedestrians who entered the tunnels were estimated by visual observation during monitoring. The vehicles were registered and classified into categories that have similar characteristics (engine and type of fuel): private cars, vans, pick-ups, trucks, buses, motorcycles and taxis (Kojima et al., 2015; Jing et al., 2016; Liu and Grigg, 2018).

To monitor the $\mathrm{CO}$ concentration, non-dispersive infrared radiation (NDIR) was used with the ALTAIR Pro Single-Gas Detector (MSA, USA). The NDIR gas sensor used a light source which passes through and interacts with the $\mathrm{CO}$ in a chamber and only a portion of the optical energy is absorbed by the $\mathrm{CO}$ at its characteristic absorption wavelengths, principally between 4.6 and $4.8 \mu \mathrm{m}$. In order to analyze the concentration of $\mathrm{CO}$, a bandpass optical filter eliminates all unwanted wavelengths in the light beam and only allows the characteristic absorption wavelengths of the CO to reach the detector (Diharja et al., 2019; Tan et al., 2020). The PM concentration $\left(\mathrm{PM}_{2.5}\right.$ and $\left.\mathrm{PM}_{10}\right)$ was evaluated using a handheld mass profiler Aerocet 831 (Met One Instruments, Inc., Grants Pass, OR, USA, 2020), based on the Rayleigh and Mie scattering theory, and specified to operate at a flow rate of $2.83 \mathrm{~L} \mathrm{~min}^{-1}$, accuracy $10 \%$ and sensitivity of $0.3 \mu \mathrm{g}$ (Borghi et al., 2018). The Aerocet sampler uses a right-angle scattering method. The interaction of the laser beam whit the particles generate the scattered light with the corresponding amplitude to size of the particle. Scattering angle and intensity depend on the size of the particles. The scattered light is 


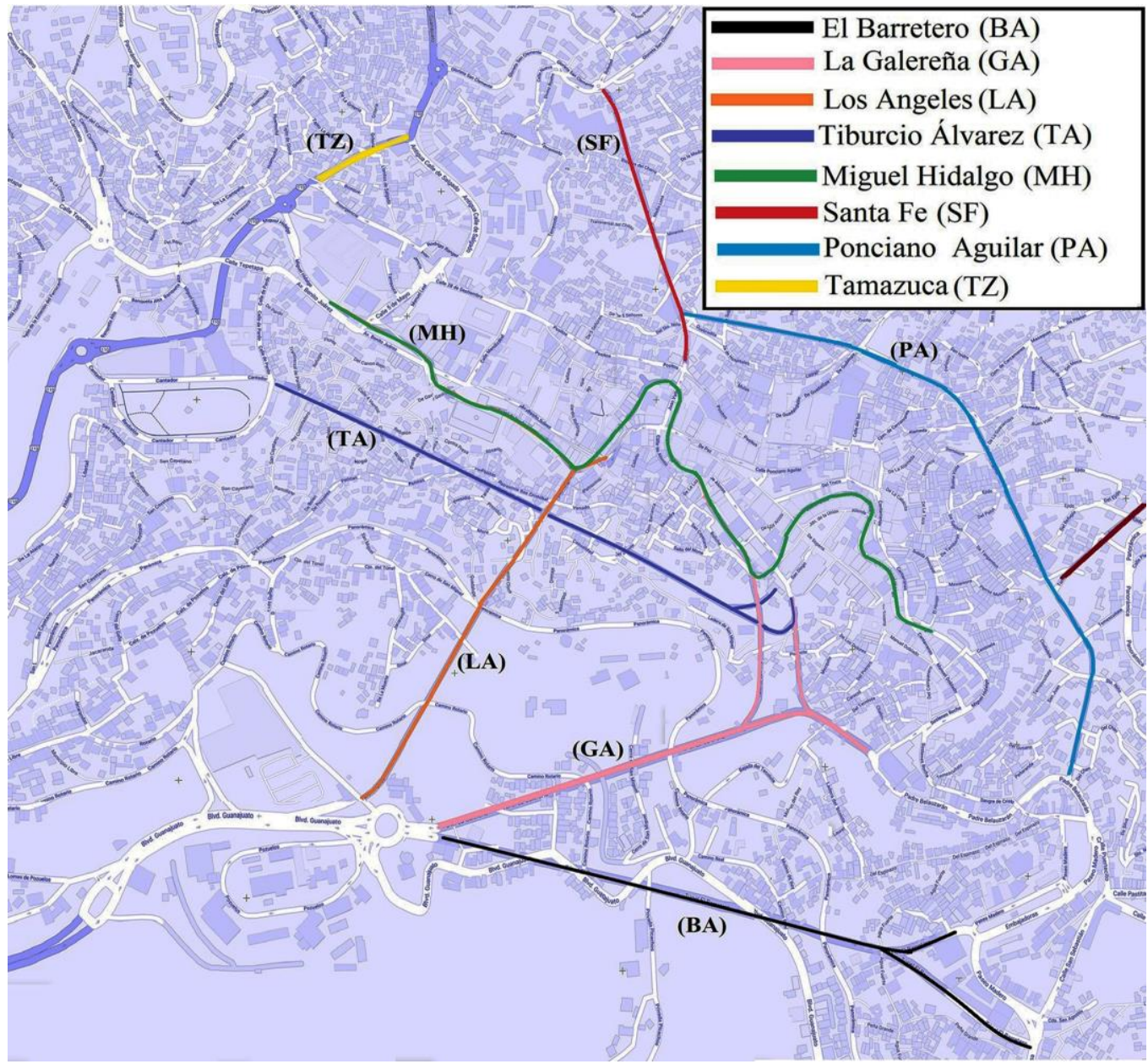

Fig. 1. Principal road tunnels in the city of Guanajuato, Mexico.

Table 1. Principal road tunnels in the city of Guanajuato.

\begin{tabular}{lllll}
\hline No. & Tunnel & Length $(\mathrm{m})$ & Time required $(\mathrm{min})$ & Slope $(\%)$ \\
\hline 1 & Barretero & 800 & 32 & 2.62 \\
2 & Ponciano Aguilar & 1100 & 52 & - \\
3 & Santa Fe & 500 & 29 & 1.6 \\
4 & Calle Hidalgo & 1100 & 23 & 2.1 \\
5 & Tamazuca & 110 & 10 & 2.1 \\
6 & Tiburcio & 950 & 25 & 1.7 \\
7 & Galereña & 700 & 35 & 6.7 \\
8 & Los Ángeles & 600 & 30 & 6.9 \\
\hline
\end{tabular}

collected over a wide angle perpendicular to the air flow and laser beam. The scattered light signal is received in a photodiode that converts it into an electrical pulse according to its amplitude that is related to the particle size. An average particle diameter is determined to calculate a volume $\left(\mathrm{m}^{3}\right)$, which is then multiplied by the number of particles and a generic density $\left(\mu \mathrm{g} \mathrm{m}^{-3}\right)$ to obtain a mass. The mass per unit volume $\left(\mu \mathrm{g} \mathrm{m}^{-3}\right)$ is determined with the resulting mass divided by the volume of air sampled (McNabola et al., 2011). For the wind speed a digital anemometer was used (Traceable ${ }^{\circledR}$ Vane Anemometer/Thermometer/Hygrometer/Dew Point Pen; Control Company, USA). This type of equipment allows us to obtain information in real time. Additionally, inside the road tunnel, the PM was captured in a circular $47 \mathrm{~mm}$ diameter glass fiber filter over a period of 8 hours, starting at 10:00 and ending at 18:00 using a MicroVol 1100 sampler (ECOTECH Pty. Ltd., USA) and three samples of dust deposited on the tunnel wall were collected about 1.5 meters 
above street level inside the studied tunnel. Elemental analysis and morphology of $\mathrm{PM}_{10}$ and $\mathrm{PM}_{2.5}$ were made using a scanning electron microscope equipped with an energy-dispersive system (JSM-6010 PLUS; JEOL, Japan). Chemical composition, mineralogy of the particulate matter and dust deposited on the wall inside the tunnel were analyzed using an energy-dispersive X-ray fluorescence spectrometer (NEX CG; Rigaku) and X-ray powder diffraction was carried out with a diffractometer (Ultima IV, Rigaku).

\section{RESULTS AND DISCUSSION}

\subsection{Vehicles}

The type and percentage of vehicles which travel in the underground network are shown in Fig. 2. These percentages represent the vehicles that circulate through the three tunnels that connect with the downtown zone of the city and form part of the underground network. As can be seen, private cars make up $41 \%$ of the total; pick-ups, $15.4 \%$; taxis, $11 \%$; buses, $11.4 \%$; vans, 7.0\%; motorcycles, 9.8\%; and trucks, 4.4\%, which concurs with other research (Jing et al., 2016; Calla and Luján, 2018). These trucks deliver goods to stores and businesses in the city. $84.2 \%$ correspond to gasoline vehicles (private cars, pick-ups, taxis and motorcycle) and $15.8 \%$ correspond to trucks and buses using diesel fuel. This $15.8 \%$ of heavy vehicles with diesel engines are the main contributors to exhaust emissions of particulate matter. Based on the urban background concentration of PM, particles from tailpipes are generally smaller than $1 \mu \mathrm{m}$. $\mathrm{PM}_{2.5}$ is mainly attributed to the exhaust pipes, brakes, and engine wear, and $\mathrm{PM}_{10}$ is related to the resuspension of road dust. As reported, a diesel vehicle emits more PM than a petrol vehicle depending on the engine's technology. The emission factors of the $\mathrm{CO}$ in exhaust gas of gasoline vehicles are about ten times more than diesel vehicles (Ferm and Sjöberg, 2015; Timmer and Achter, 2016; Platt et al., 2017). Thus, the CO concentration is generated by gasoline cars principally and the PM can be generated by the exhaust pipe or resuspended dust.

\subsection{Pedestrian and Permissible Length of Tunnel with Natural Ventilation}

Counting the pedestrians, their number ranged from 35 to 300 persons per hour and the highest counts corresponded to Calle Hidalgo which is the principal tunnel with bus stops and a parking zone (Table 2). The Barretero, Santa Fe and Los Ángeles tunnels offer a much shorter distance to walk in contrast to its over-ground alternative. Those tunnels are mainly used by students attending nearby schools; the Santa Fe tunnel is an optional access to the main buildings of banks and the University of Guanajuato; Barretero and Los Ángeles are a shortcut to the commercial plaza Pozuelos and some government offices. In four other tunnels (Galereña, Ponciano Aguilar, Tiburcio and Tamazuca) the number of pedestrians was 35-160 per hour. Relatively few persons walk through Galereña because the entrance to this tunnel is located far away from the city center, where the over-ground streets are more convenient for pedestrians.

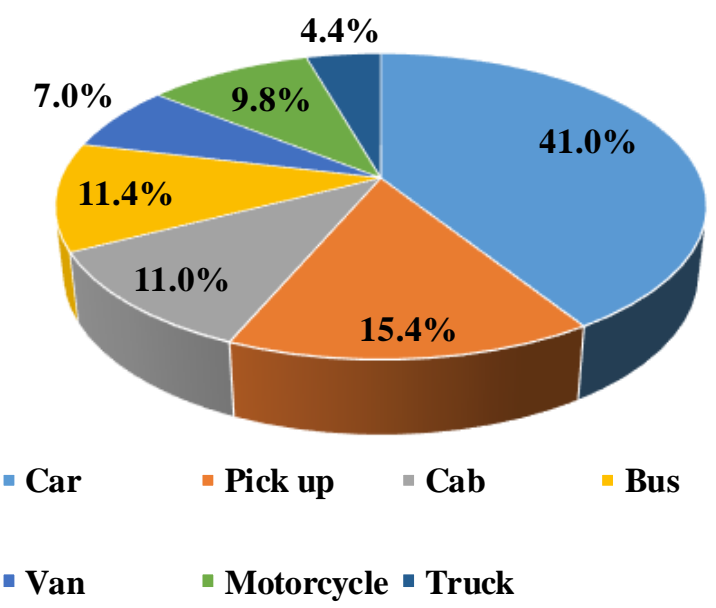

Fig. 2. Percentage of types of vehicles which travel in the underground tunnels. 
Table 2. Pedestrian use, vehicles, and permissible length of eight principal road tunnels.

\begin{tabular}{llllll}
\hline No. & Tunnel & Length $(\mathrm{km})$ & Pedestrian use & Vehicles $\mathrm{h}^{-1}\left(\mathrm{M}_{\max }\right)$ & Permissible length $(\mathrm{km})$ \\
\hline 1 & Barretero & 0.800 & $210 \pm 28$ & $653 \pm 161$ & 0.4914 \\
2 & Ponciano Aguilar & 1.100 & $78 \pm 12$ & $278 \pm 67$ & 1.1590 \\
3 & Santa Fe & 0.500 & $260 \pm 30$ & $349 \pm 28$ & 1.061 \\
4 & Calle Hidalgo & 1.100 & $300 \pm 34$ & $332 \pm 76$ & 0.9803 \\
5 & Tamazuca & 0.110 & $96 \pm 13$ & $586 \pm 74$ & 0.6060 \\
6 & Tiburcio & 0.950 & $160 \pm 15$ & $342 \pm 45$ & 1.0335 \\
7 & Galereña & 0.700 & $35 \pm 4$ & $485 \pm 32$ & 0.7736 \\
8 & Los Ángeles & 0.600 & $230 \pm 25$ & $425 \pm 53$ & 0.8368 \\
\hline
\end{tabular}

Using the number of vehicles traveling during 1 hour inside the tunnels, the permissible length in kilometers of the eight naturally ventilated tunnels was calculated by Eq. (1) (Table 2). The Barretero $(0.800 \mathrm{~km})$ and Calle Hidalgo $(1.100 \mathrm{~km})$ tunnels exceed the allowable length. However, the Calle Hidalgo tunnel has short sections of approximately 150 meters and then sections open to the air of 120 meters. The permissible length of $0.49 \mathrm{~km}$ suggests that the Barretero tunnel must have mechanical ventilation to ensure good air quality. On the other hand, Galereña, Los Ángeles, Tamazuca, Santa Fe, Ponciano Aguilar and Tiburcio tunnels comply with the permissible length (PIARC, 2004).

\subsection{CO, $\mathrm{PM}_{2.5}$ and $\mathrm{PM}_{10}$ Concentration inside the Tunnels}

To validate the results and determine the air quality inside the tunnels, the monitoring of $\mathrm{CO}$, $\mathrm{PM}_{2.5}$ and $\mathrm{PM}_{10}$ concentrations was made. The average and maximums of the concentrations recorded in the monitoring of $\mathrm{CO}, \mathrm{PM}_{2.5}$ and $\mathrm{PM}_{10}$ in the tunnels studied are shown in Fig. 3. As can be seen, the Los Ángeles, Galereña and Barretero tunnels have the highest average concentrations of $\mathrm{CO}(17,21$ and $18 \mathrm{ppm}$ respectively) and the corresponding maximums of 67,47 and $25 \mathrm{ppm}$ of CO respectively. This result is consistent with the highest slope recorded in the tunnels (Table 1). The maximum concentration of $\mathrm{PM}_{2.5}$ and $\mathrm{PM}_{10}$ was registered in LA (160 and $183 \mu \mathrm{g} \mathrm{m}^{-3}$ ), BA ( 89 and $102 \mu \mathrm{g} \mathrm{m}^{-3}$ ), GA (78 and $84 \mu \mathrm{g} \mathrm{m}^{-3}$ ) and Calle Hidalgo (75 and $84 \mu \mathrm{g} \mathrm{m}^{-3}$ ). Thus, based on $\mathrm{CO}, \mathrm{PM}_{2.5}, \mathrm{PM}_{10}$ concentration and length, Los Ángeles, Galereña and Barretero tunnels were selected to monitor the pollutants for one week and evaluate the air quality.

Air quality inside the LA, GA and BA tunnels was studied and the maximum concentrations of $\mathrm{CO}, \mathrm{PM}_{2.5}, \mathrm{PM}_{10}$, wind speed and vehicle flow were analyzed for each day in one week as shown

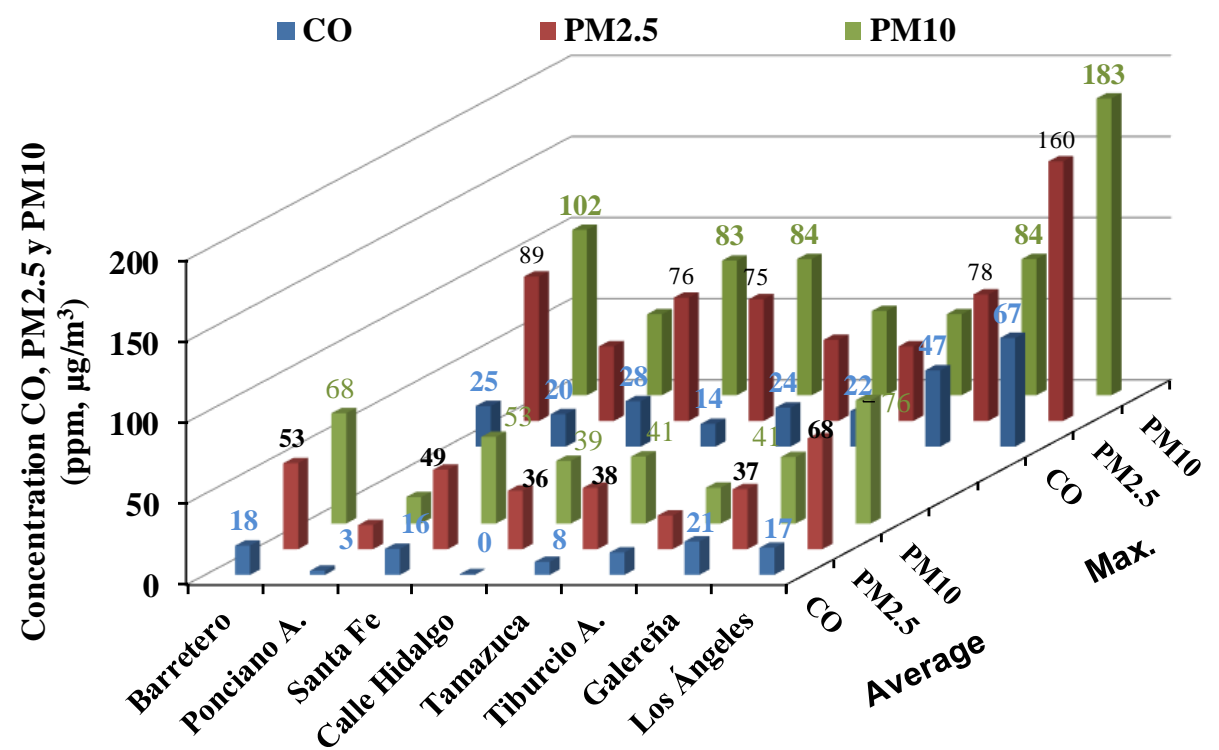

Fig. 3. Average and maximum concentrations of $C O, P_{2.5}$, and $P_{10}$ in eight road tunnels of Guanajuato. 
in Fig. 4. As can be seen, the maximum concentration of $\mathrm{PM}_{2.5}$ and $\mathrm{PM}_{10}$ was recorded on Wednesday for the LA and GA tunnels. The maximum concentration agrees very well with a maximum in the vehicular flow and the speed of the wind generated by the same vehicles inside LA and GA tunnels. However, in the BA tunnel the maximum concentration was registered on Tuesday, and the maximum concentration of $\mathrm{PM}_{2.5}$ and $\mathrm{PM}_{10}$ corresponds to a minimum in vehicle flow and wind speed inside the BA tunnel. This result is attributed to the vehicular congestion within the BA tunnel, generating a stagnation of the pollutants due to the low wind speed because the vehicles are forced to stop and drive at a very low speed, diminishing the piston effect that pushes the pollutant outside the tunnel (Dong et al., 2017).

The principal CO source is the tailpipe and the PM source can be both from the tailpipe (exhaust emissions) and non-exhaust emissions due to wear and tear of the vehicle's engine, brake, tire, and clutch. Additionally, resuspension of dust (non-exhaust emissions) contributes predominantly to the coarse particles ( $\mathrm{PM}_{2.5-10}$ ) while exhaust emissions contribute predominantly to the fine particles. Other parameters such as vehicle speed, type of vehicle, driving conditions, tire conditions, type of fuel used, road surface and slope are important in pollutant generation (Timmers and Achten, 2016).

The average concentrations of $\mathrm{CO}, \mathrm{PM}_{2.5}$ and $\mathrm{PM}_{10}$ recorded within the three tunnels studied (LA, GA and BA) are plotted in Fig. 5. For any day of the week, the mean CO concentration does not exceed the $87 \mathrm{ppm}$ for an exposure time of 15 minutes. Based on the World Health Organization (WHO), these concentrations are within the maximum limits allowed for $\mathrm{CO}$, indicating good air quality within the tunnels for this pollutant. On the other hand, the average concentrations for $\mathrm{PM}_{10}$ in the three tunnels (LA: $95 \mu \mathrm{g} \mathrm{m}^{-3}$, GA: $108 \mu \mathrm{g} \mathrm{m}^{-3}$, and BA: $93 \mu \mathrm{g} \mathrm{m}^{-3}$ ) are above the maximum permissible limit of $50 \mu \mathrm{g} \mathrm{m}^{-3}$ average every 24 hours recommended for the air quality inside the tunnels (WHO). These results show that inside the studied tunnels in the city of Guanajuato there is poor air quality based on the $\mathrm{PM}_{10}$ concentrations. Some authors have reported average $\mathrm{PM}_{10}$
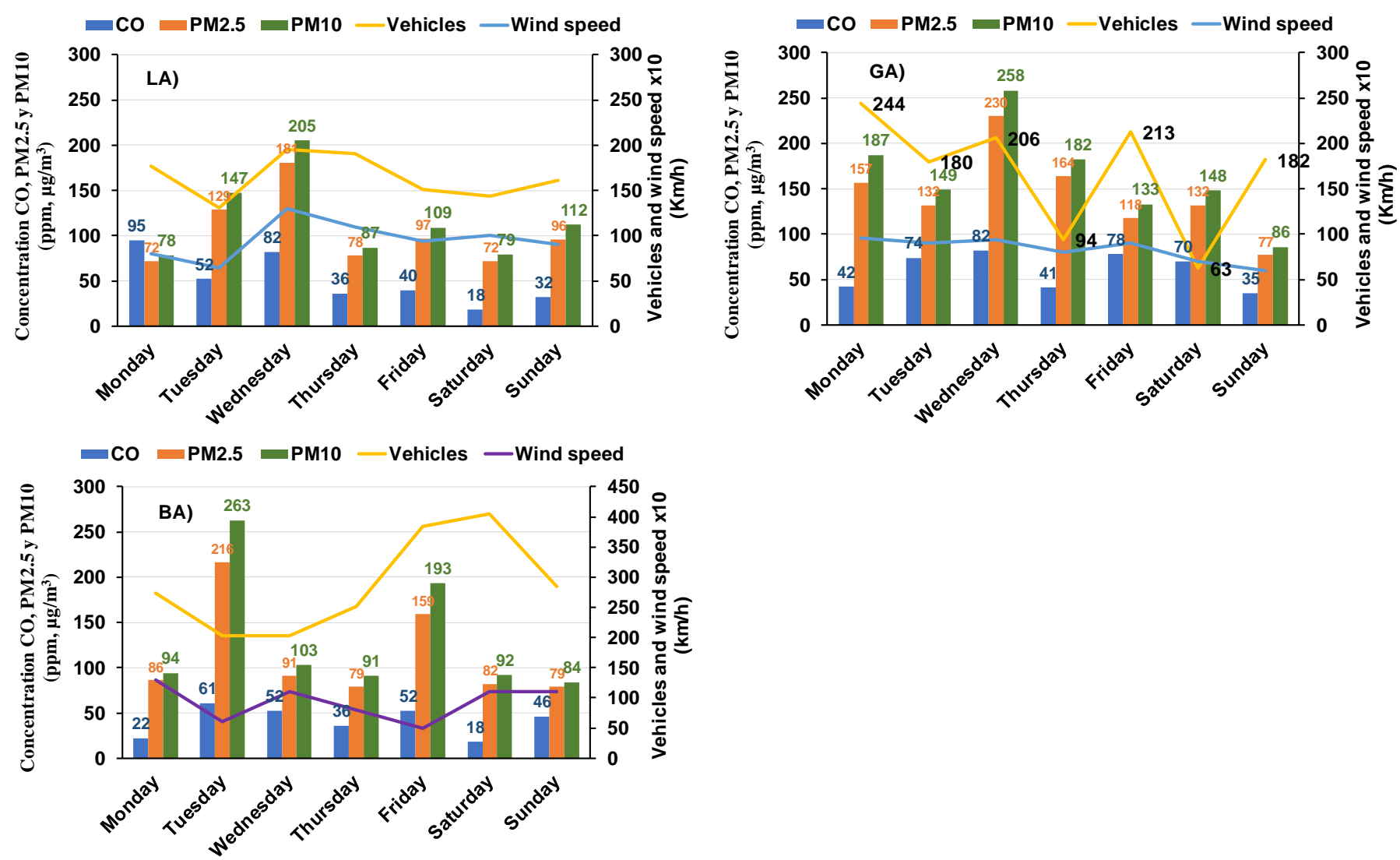

Fig. 4. Maximum concentrations of $\mathrm{CO}, \mathrm{PM}_{2.5}$, and $\mathrm{PM}_{10}$ contrasting the number of vehicles and wind speed for the days of the week: Los Ángeles (LA), Galereña (GA), and Barretero (BA). 


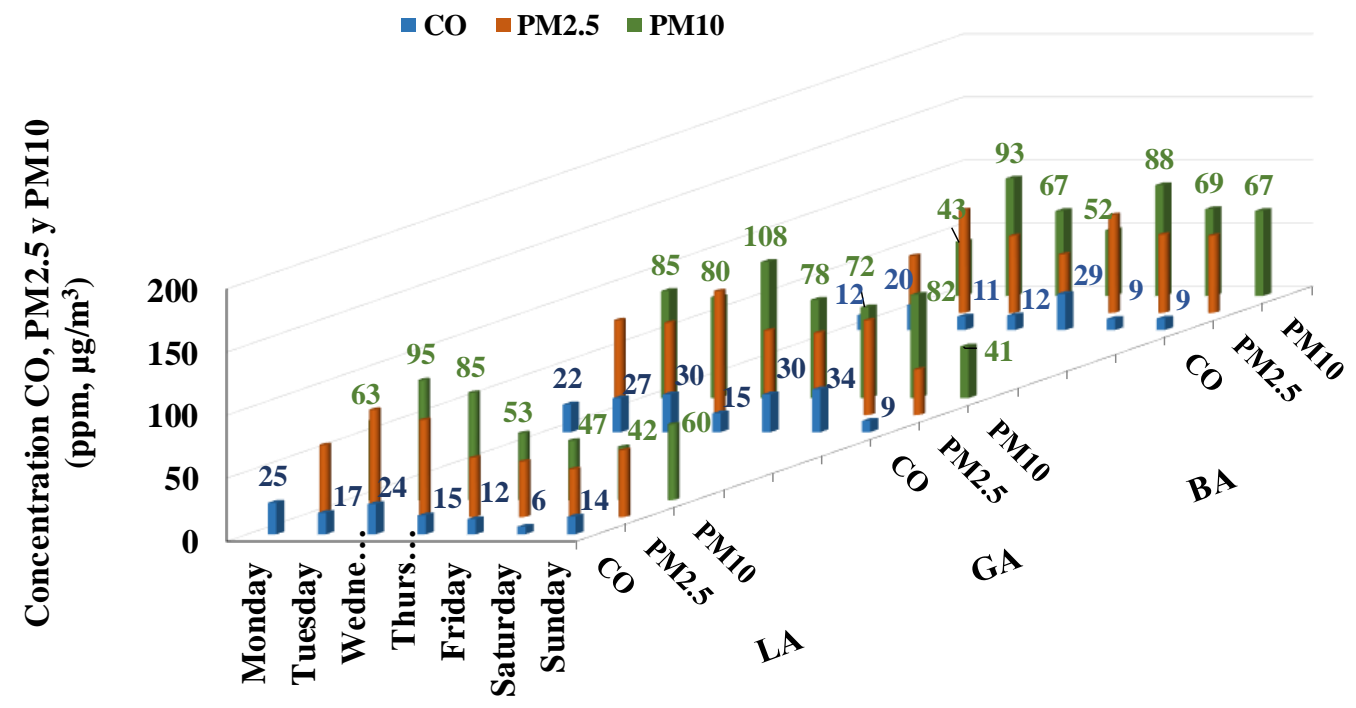

Fig. 5. Average concentrations of $\mathrm{CO}, \mathrm{PM}_{2.5}$, and $\mathrm{PM}_{10}$ inside the three tunnels: Los Ángeles (LA), Galereña (GA), and Barretero (BA).

(178 $\mu \mathrm{g} \mathrm{m}^{-3}$ ) and $\mathrm{PM}_{2.5}\left(468 \mu \mathrm{g} \mathrm{m}^{-3}\right.$ ) levels inside the road tunnels in Taiwan and Shanghai, respectively (Ma et al., 2011; Zhou et al., 2014). Table 3 summarizes the maximum concentration peaks (and averages) in one day registered with those recommended by international organizations inside road tunnels.

As mentioned, the concentration variation of pollutants inside the tunnel depends on many factors: number of vehicles, tire wear, vehicle speeds, engine type, fuel type, operating conditions, vehicle characteristics, wind speed, vehicle turbulence and resuspension of particulate matter. For Tuesday, Fig. 6 displays the $\mathrm{CO}, \mathrm{PM}_{2.5}$ and $\mathrm{PM}_{10}$ concentration profile against the number of vehicles and wind speed for each tunnel (LA, GA and BA). The monitoring of the pollutants was made in rush hours (13:00-14:00). The data were taken every 60 meters inside each tunnel during the time it takes the pedestrian to go through the inside of the tunnels, about 30, 32 and 35 minutes for LA, BA and GA tunnels respectively. It is important to mention that the traffic of the LA and GA tunnels exits the city, versus the flow of traffic of the BA tunnel going toward the center of the city.

The BA tunnel, with a higher vehicular flow is one of the most important entrances to the center of Guanajuato, generating congestion and slow movement of traffic in the rush hour, in comparison with the LA and GA used as exit tunnels from the center of the city. As can be seen in Fig. 6, corresponding to the BA tunnel, the vehicular congestion with low vehicular flow concurs with the maximums of pollutant concentrations $\left(\mathrm{PM}_{2.5}\right.$ and $\left.\mathrm{PM}_{10}\right)$ observed at 300,400 and 650 meters, approximately (Dong et al., 2017). On the other hand, a progressive increase of the $\mathrm{PM}_{2.5}$ and $\mathrm{PM}_{10}$ concentration is generated with the vehicular flow and wind speed from the entrance to the exit of LA and GA tunnels showing the absence of vehicular congestion inside the tunnels. In fact, the continuous vehicular flow maintains an air flow through the tunnels and its velocity depends on vehicular number and vehicular velocity. So, the maximum concentration of $\mathrm{PM}_{2.5}$ and $\mathrm{PM}_{10}$ is observed in the exit tunnels due to the pollutant drag produced by the air stream in vehicular flow direction without congestion (Qiong et al., 2015; Wang et al., 2016).

The natural concentration of carbon monoxide in air is about $0.2 \mathrm{ppm}$ (Fazlzadeh et al., 2015). So, the concentration of $\mathrm{CO}$ at the entrance of the LA and GA tunnels was less than $1 \mathrm{ppm}$ as

Table 3. The maximum concentration peaks (and averages) in one day registered with those recommended by international organizations inside road tunnels.

\begin{tabular}{lllllll}
\hline & LA & GA & BA & EPA & WHO & PIARC \\
\hline PM $_{10}\left(\mu \mathrm{g} \mathrm{m}^{-3}\right)$ & $205(95)$ & $258(108)$ & $263(93)$ & $50(24 \mathrm{~h})$ & $50(24 \mathrm{~h})$ & - \\
$\mathrm{CO}(\mathrm{ppm})$ & $95(25)$ & $82(30)$ & $61(29)$ & $87(15 \mathrm{~min})$ & $87(15 \mathrm{~min})$ & $100(15 \mathrm{~min})$ \\
\hline
\end{tabular}



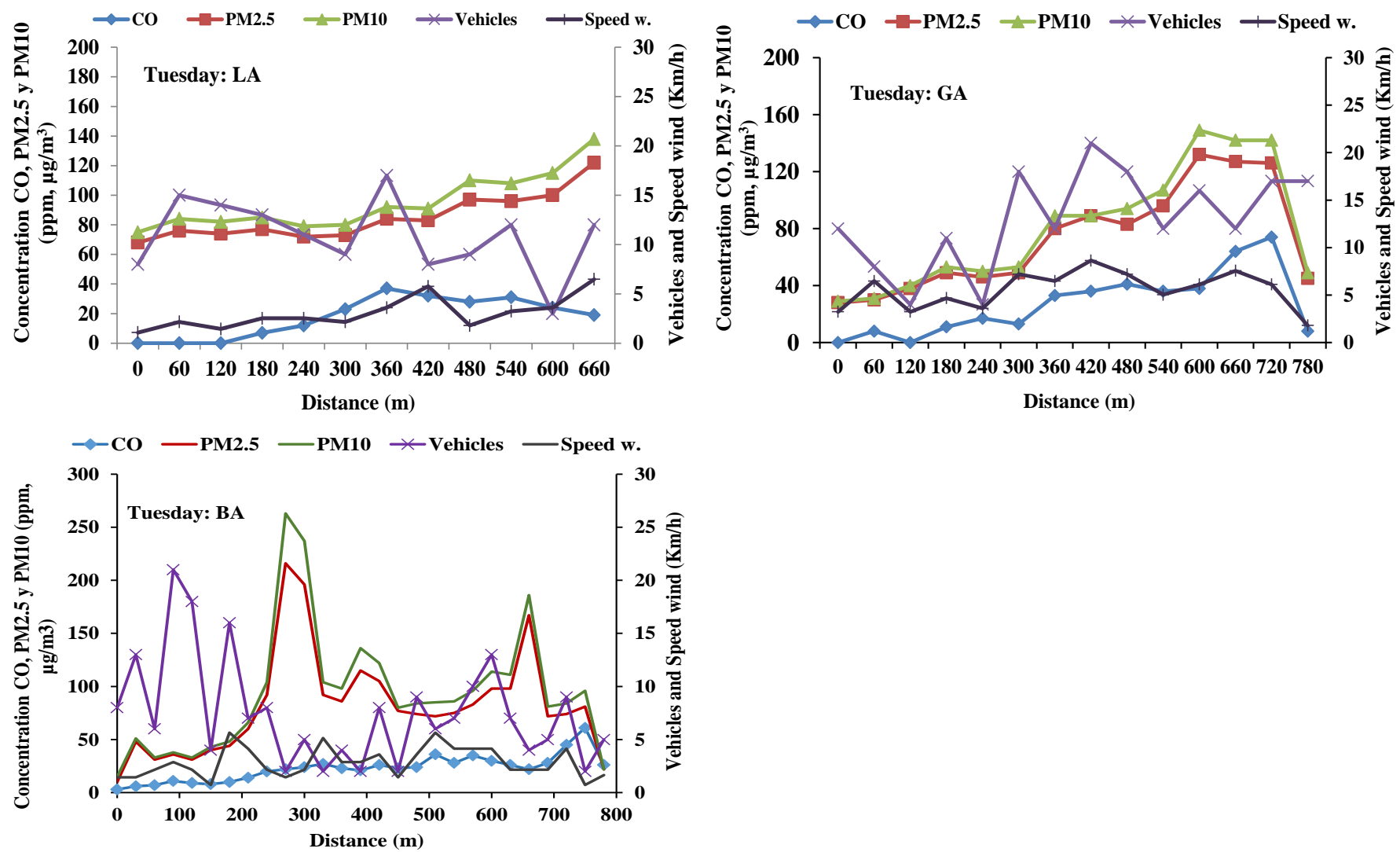

Fig. 6. Concentration profile of pollutants $\left(C O, \mathrm{PM}_{2.5}\right.$, and $\left.\mathrm{PM}_{10}\right)$ contrasting the number of vehicles and wind speed inside the tunnels: Los Ángeles (LA), Galereña (GA), and Barretero (BA).

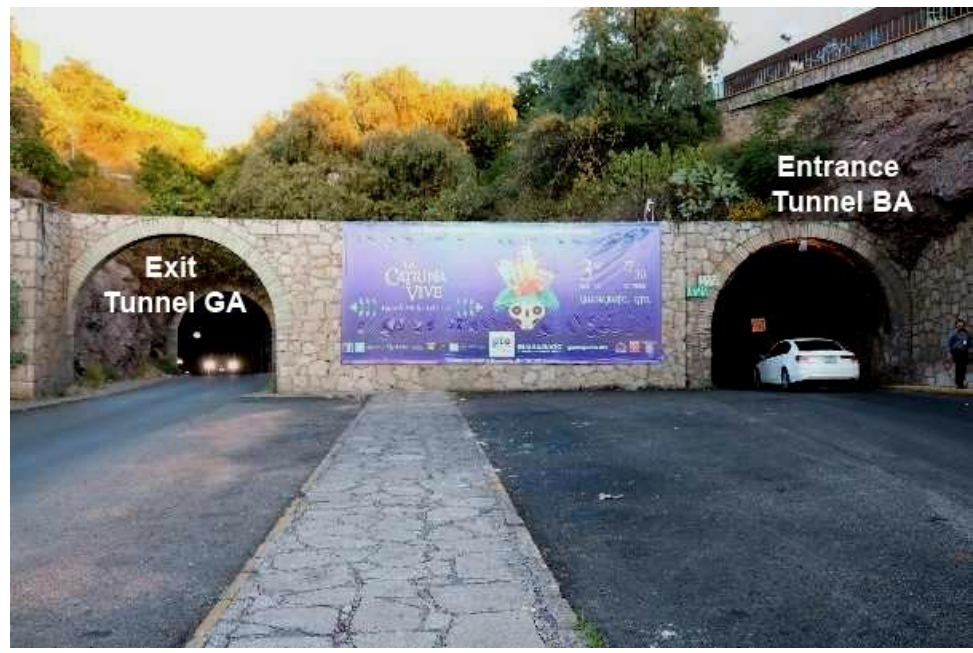

Fig. 7. Exit of the Galereña tunnel (GA) and entrance to the Barretero tunnel (BA).

shown in Fig. 6. Fig. 7 shows two independent tunnels; one is the Galereña tunnel exit, and the other is the Barretero tunnel entrance. The two tunnels do not communicate with each other. However, at the entrance in the BA tunnel, concentrations of $3 \mathrm{ppm}$ were registered, and this can be because the entrance of BA tunnel is close to the exit of GA tunnel and the greater vehicular flow to the center of the city by the BA tunnel (Fig. 7).

As can be seen in Fig. 6, the variation of the concentration of $\mathrm{CO}$ inside the tunnels is directly related to the number of vehicles entering them and to the variations in the wind speed that generates turbulence of the toxic gases towards the exit of the tunnels (Brimblecombe et al., 
2015; Dong et al., 2017). During the monitoring on Tuesday, 131 vehicles entered in the 30 minutes during the monitoring time from the entrance to exit of LA tunnel, 203 vehicles traveled through the BA tunnel in 32 minutes and 182 vehicles went through the GA tunnel in 35 minutes during the monitoring time. In all cases, the concentration of $\mathrm{CO}$ increases from entrance to exit of tunnels.

\subsection{Emission Factors}

The EFs were determined based on a balance model of matter of each pollutant emitted inside the tunnel (Zhao et al., 2018a). The difference between the mass of contaminant that leaves the tunnel and the contaminant that enters the tunnel is the quantity that is emitted inside. Thus, it is possible to estimate the emission ratio of each pollutant in terms of emitted mass of pollutant per vehicle per driven distance ( $\mathrm{mg}$ vehicles ${ }^{-1} \mathrm{~km}^{-1}$ ), by means of the following expression (Gillies et al., 2001; Franco et al., 2013):

$E F=\left(C_{e}-C_{i}\right) \times V T / N L$

where $C_{e}$ and $C_{i}$ represent the pollutant concentrations $\left(\mathrm{mg} \mathrm{m}^{-3}\right)$ at the exit and entrance of the tunnel, respectively. In addition, $V$ represents the volumetric flow of air $\left(\mathrm{m}^{3} \mathrm{~s}^{-1}\right)$ entering or leaving the tunnel, $\mathrm{T}$ is the monitoring time in seconds, $\mathrm{N}$ is the number of vehicles passing through the tunnel and $\mathrm{L}$ is the distance traveled in kilometers between both points.

The average $\mathrm{EF}$ for the mixed vehicles corresponding to the $\mathrm{CO}, \mathrm{PM}_{2.5}$ and $\mathrm{PM}_{10}$ pollutants and the randomly chosen seven days of the week are shown in Table 4. Standard deviations of the emission factors obtained for the seven days of the week are indicated in parentheses. A high standard deviation indicates that the EF for each day is spread out over a large range of values or that they are very dispersed. This is because the number of vehicles, engine conditions, fuel used, type and vehicular speed vary from day to day in each tunnel. The highest EFs were recorded in the Galereña tunnel for the three pollutants studied (CO: 50,644, PM 2.5: 132.35 , and $\mathrm{PM}_{10}$ : 144.75) and the lowest EFs obtained were in the Barretero tunnel which has the smallest slope (Tables 1 and 4). The EFs corresponding to $\mathrm{CO}$ concur with other recommended vehicle emission factors (Wang et al., 2018).

The lowest values of the EFs were recorded in the Barretero road tunnel (CO: 17,311, PM 2.5: 36.64, and $\mathrm{PM}_{10}$ : 37.43); however, the values of the EFs are very high compared to those reported by other researchers (Zhao et al., 2018a). These high results of the EFs in the tunnels Barretero, Galereña and Los Ángeles suggest a ventilation system inside the tunnels be implemented.

\subsection{CO-PM ${ }_{10}$ Correlation Values of Concentration}

Considering the similar behavior of the $\mathrm{PM}_{10}$ and $\mathrm{PM}_{2.5}$ inside the tunnel, only the correlation between $\mathrm{CO}$ and $\mathrm{PM}_{10}$ was evaluated, which would be very similar to the correlation that would be obtained between $\mathrm{CO}$ and $\mathrm{PM}_{2.5}$ (Fig. 8). Using the values obtained of the concentration of the pollutants $C O$ and $P M_{10}$, the value of the correlation coefficient $\left(R^{2}\right)$ was determined using

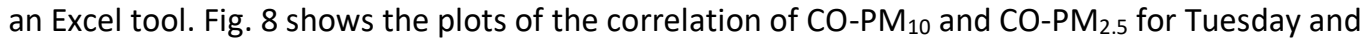
as can be seen the $R^{2}$ values are very approximate. The $R^{2}$ values of the correlation between measured concentration of $C O$ versus $\mathrm{PM}_{10}$ inside $\mathrm{LA}, \mathrm{GA}$ and $\mathrm{BA}$ tunnels for the randomly selected

Table 4. Average emission factors (EFs; mg vehicles ${ }^{-1} \mathrm{~km}^{-1}$ ).

\begin{tabular}{lllll}
\hline Tunnel/pollutant & $\mathrm{CO}$ & $\mathrm{PM}_{2.5}$ & $\mathrm{PM}_{10}$ & Ref. \\
\hline Barretero & $17,311( \pm 594)$ & $36.64( \pm 24)$ & $37.43( \pm 26)$ & This paper \\
Galereña & $50,644( \pm 1557)$ & $132.350( \pm 35)$ & $144.75( \pm 4619$ & This paper \\
Los Ángeles & $36,420( \pm 1051)$ & $64.47( \pm 249$ & $70.52( \pm 23)$ & This paper \\
Australia & - & $26( \pm 10)$ & $62( \pm 18)$ & Handler et al. (2008) \\
Wenchang Gate-Peace Gate Tunnel, China & $1097( \pm 398)$ & $6( \pm 5)$ & - & Zhao et al. (2018b) \\
Zhujiang Tunnel, China & $3096( \pm 680)$ & - & - & Zhao et al. (2018b) \\
Monterrey-San Pedro Bore, Mexico & $11,800( \pm 3880)$ & $13.3( \pm 6.3)$ & - & Mancilla et al. (2012) \\
Mexico & - & - & $22.8( \pm 7.4)$ & Pant and Harrison (2013) \\
\hline
\end{tabular}


- BA $\quad$ LA

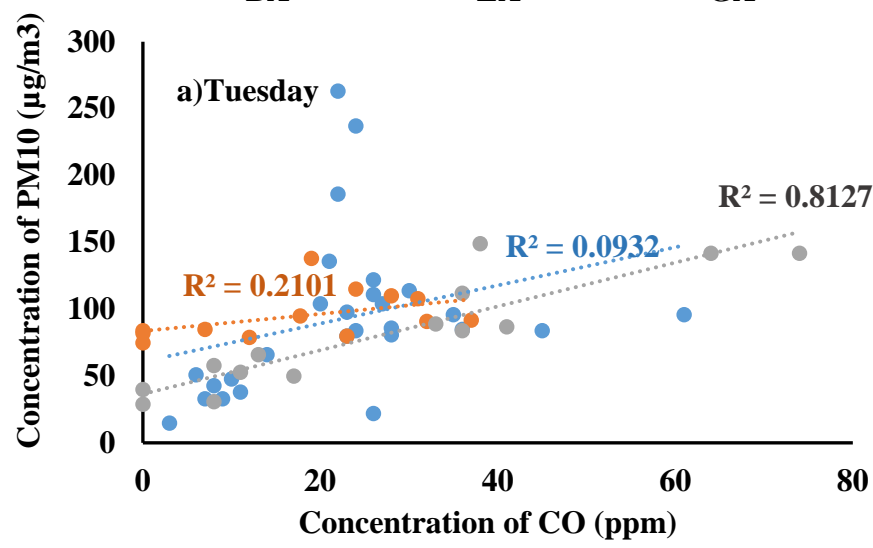

- BA

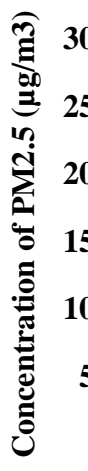

- LA

- GA

Fig. 8. Correlation inside the tunnels $L A, G A$, and $B A$ on Tuesday: (a) CO-PM10 and (b) CO-PM2.5.

Table 5. CO-PM 10 correlation values.

\begin{tabular}{llll}
\hline & \multicolumn{3}{c}{ CO-PM10 correlation $\left(\mathrm{R}^{2}\right)$} \\
\cline { 2 - 4 } & Los Ángeles & Galereña & Barretero \\
\hline Monday & 0.41 & 0.46 & 0.12 \\
Tuesday & 0.21 & 0.81 & 0.09 \\
Wednesday & 0.62 & 0.17 & 0.32 \\
Thursday & 0.75 & 0.46 & 0.25 \\
Friday & 0.80 & 0.53 & 0.24 \\
Saturday & 0.43 & 0.74 & 0.15 \\
Sunday & 0.63 & 0.17 & 0.11 \\
Average $\left(\mathrm{R}^{2}\right)$ & 0.55 & 0.48 & 0.18 \\
\hline
\end{tabular}

days of one week are presented in Table 5 . The $R^{2}$ values vary from 0.21 to $0.80,0.17$ to 0.81 and 0.09 to 0.32 inside LA, GA and BA, respectively. This is consistent with the fact that each pollutant is generated from a different source and concentrations depend on many factors: the number of vehicles, tire wear, vehicle speeds, engine type, operating conditions, fuel type and wind speed.

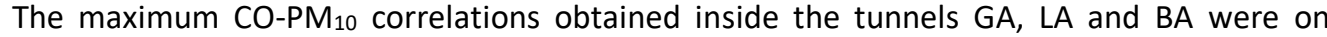
Tuesday $\left(R^{2}=0.84\right)$, Friday $\left(R^{2}=0.80\right)$ and Wednesday $\left(R^{2}=0.32\right)$, respectively. Figs. $8(a)$ and $8(b)$ show the correlation of $\mathrm{CO}$ versus $\mathrm{PM}_{10}$ and $\mathrm{PM}_{2.5}$ concentrations registered on Tuesday. As can be seen the $R^{2}$ values corresponding to the pollutant concentrations inside the tunnel vary a lot from each other. This behavior was obtained each day of the week (Table 5). The low average of the $R^{2}$ values for the seven days of the week suggests a small correlation between CO-PM concentrations inside the tunnels because the pollutants are generated by different sources: The $\mathrm{CO}$ source is the tailpipe and the principal source of the particulate matter $\left(\mathrm{PM}_{10}\right.$ and $\left.\mathrm{PM}_{2.5}\right)$ is resuspension (non-exhaust emissions).

\subsection{Scanning Electron Microscopy-energy Dispersive X-ray Spectroscopy (SEM- EDS) Analysis}

SEM combined with EDS is a widely used technique to study the particulate morphology and elemental composition. The morphology and chemical composition of atmospheric particle matter have been studied in recent years due to effect on human health (Satsangi et al., 2014 Zeb et al., 2018;). SEM-EDS was used to determine the morphology of the particles captured on a glass fiber filter. Fig. 9 shows particles in a solid state with an irregular morphology in all cases. These characteristics correspond to the $\mathrm{PM}_{2.5}$ particles from car exhaust and soil dust. As reported, dust particles ( $\mathrm{PM}_{10}$ and $\mathrm{PM}_{2.5}$ ) are mostly mineral dust (Zhang et al. 2017). Inside a tunnel, vehicular traffic and wind currents cause the resuspension of heavy dust on the road surface (Ferm and Sjöberg, 2015). 
On the other hand, EDS analysis shows the predominant elemental composition of the glass fiber filter which consisted of $\mathrm{O}, \mathrm{Si}, \mathrm{Al}, \mathrm{Ca}$ and $\mathrm{Mg}$, and, from the $\mathrm{PM}$, of $\mathrm{O}, \mathrm{Si}, \mathrm{Ca}, \mathrm{Al}, \mathrm{Fe}, \mathrm{Mg}, \mathrm{S}$, $\mathrm{Na}$ and Ti principally (Fig. 10). The chemical composition of particles principally corresponds to the resuspension of mineral dust and this result was similar in LA, GA and BA indicating the effectiveness of processes that influence mineral dust resuspension, generated by the vehicular flow and wind speed inside the tunnel (Pant and Harrison, 2013; Grivas et al., 2012).
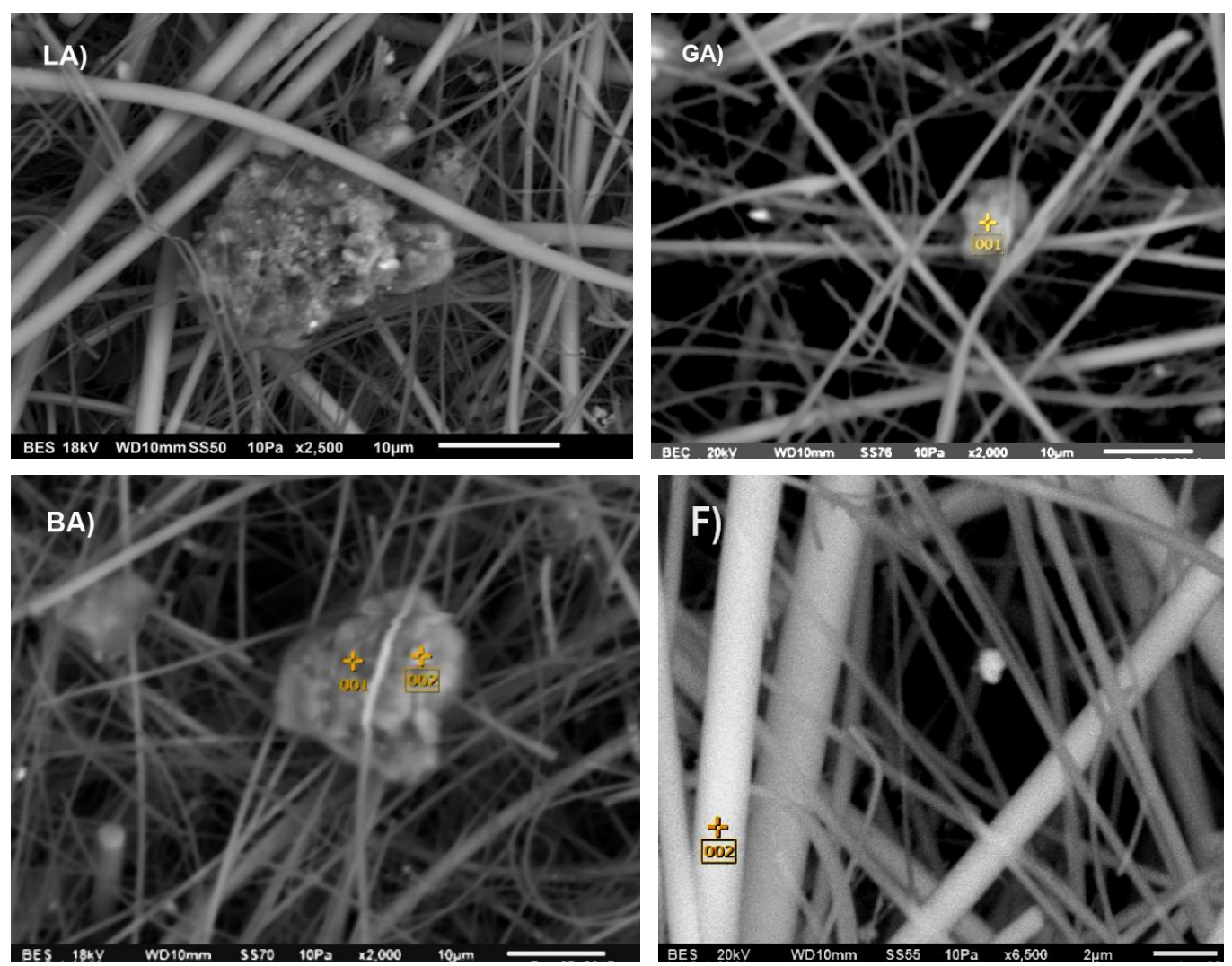

Fig. 9. Morphological analysis (SEM) of the filter (F) and PM inside road tunnels: Los Ángeles (LA), Galereña (GA), and Barretero (BA).

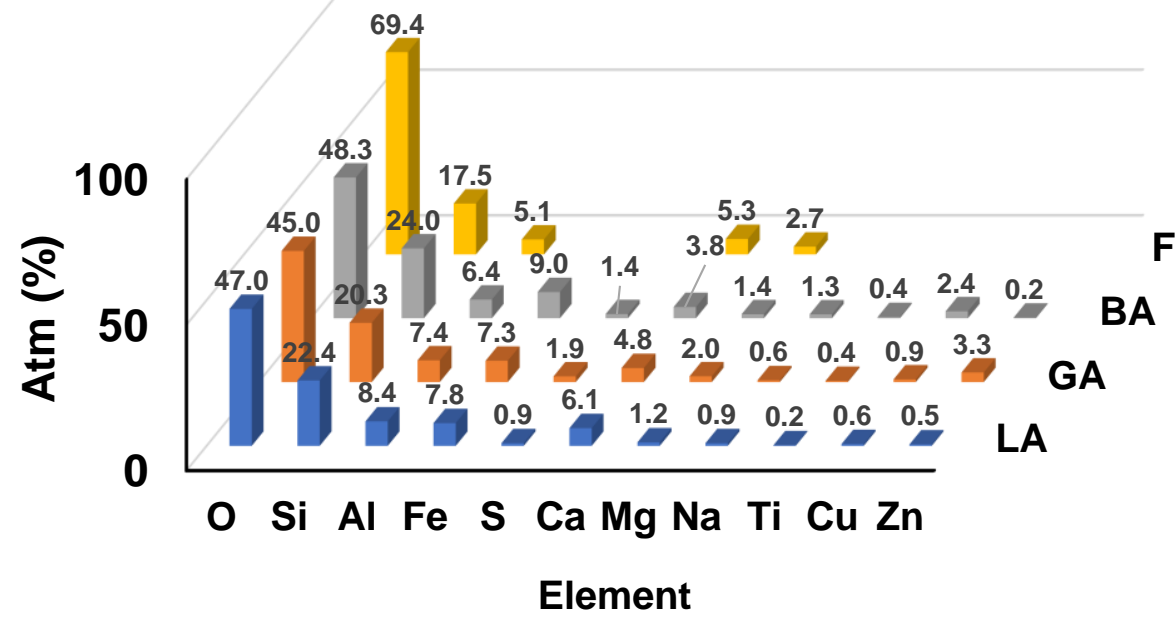

Fig. 10. Elemental analysis (EDS) of the filter (F) and PM inside road tunnels: Los Ángeles (LA), Galereña (GA), and Barretero (BA). 


\subsection{X-ray Fluorescence (XRF) Spectroscopy}

A quantitative chemical analysis of the dust deposited on the tunnel walls was performed by XRF spectroscopy. The six samples analyzed were collected about 1.5 meters above the street level inside each tunnel. Fig. 11 shows the weight percentages of principal elements present in the dust sample collected inside LA, GA and BA tunnels. As can be seen, the composition of the powder in all cases is almost equal, containing $\mathrm{O} \gg \mathrm{Si}>\mathrm{Fe}>\mathrm{Al}>\mathrm{S}>\mathrm{Ca}, \mathrm{Mg}, \mathrm{K}, \mathrm{Ti}$ and $\mathrm{Pb}$. These results concur with those obtained by SEM-EDS, which, based on its chemical composition corresponds to the mineral dust derived from rock erosion (rhyolite mainly), soil, and material used for fortification.

\subsection{X-ray Diffraction (XRD) Pattern for Powder Samples}

The XRD pattern of the dust sample collected inside LA, GA and BA tunnels is shown in Fig. 12. The particles were examined and have the composition like that of the aluminosilicates, sulfates, and carbonates. The origin of aluminosilicate particles ( $\mathrm{Al}, \mathrm{Si}, \mathrm{Ca}, \mathrm{Al}, \mathrm{Si}, \mathrm{Fe}, \mathrm{K}$ and minor elements $\mathrm{Na}, \mathrm{Mg}, \mathrm{Ti}, \mathrm{Mn}, \mathrm{Ni}$ and $\mathrm{Zn}$ ) is mainly crustal and resuspension of dust from road. Moreover, the $\mathrm{Fe}$ and $\mathrm{Pb}$ can be generated by the abrasion of metallic materials and traffic-related sources. As observed, the main peaks of crystalline phases correspond to quartz $\left(\mathrm{SiO}_{2}\right)$, gypsum $\left(\mathrm{CaSO}_{4} \cdot 2 \mathrm{H}_{2} \mathrm{O}\right)$, albite $\left[\mathrm{Na}\left(\mathrm{Si}_{3} \mathrm{Al}\right) \mathrm{O}_{8}\right]$, anorthite $\left(\mathrm{CaAl}_{2} \mathrm{Si}_{2} \mathrm{O}_{8}\right)$, calcite $\left(\mathrm{CaCO}_{3}\right)$, jeppeite $\left[(\mathrm{K}, \mathrm{Ba})_{2}\left(\mathrm{TiFe}^{3+}\right)_{6} \mathrm{O}_{13}\right]$, mikasaite

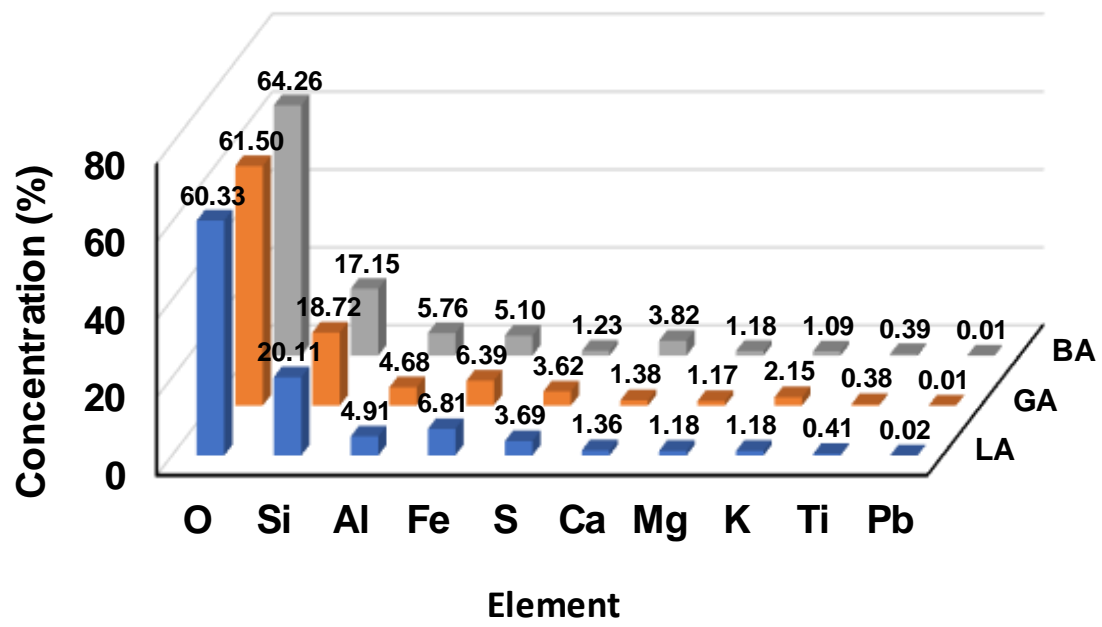

Fig. 11. Chemical composition of powder inside the tunnels: Los Ángeles (LA), Galereña (GA), and Barretero (BA).

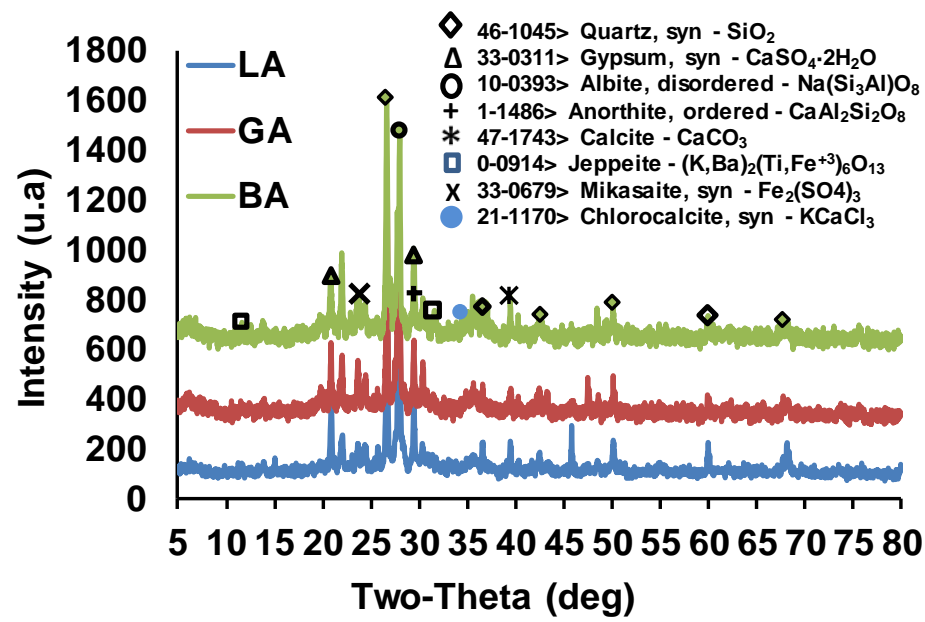

Fig. 12. $X$-ray diffraction (XRD) of the powder collected on the tunnel walls: Los Ángeles (LA), Galereña (GA), and Barretero (BA). 
[ $\left.\mathrm{Fe}_{2}\left(\mathrm{SO}_{4}\right)_{3}\right]$ and chlorocalcite $\left(\mathrm{KCaCl}_{3}\right)$. The mineralogical composition of dust indicates that natural pollutants such as $\mathrm{Si}, \mathrm{Al}, \mathrm{Fe}, \mathrm{Ca}$ and $\mathrm{Mg}$ originate from the erosion and soil wear $\left(\mathrm{SiO}_{2}\right)$, and crustal materials containing $\mathrm{CaCO}_{3}$. The $\mathrm{CaCO}_{3}$ corresponds to the natural calcium carbonate of the sedimentary rock. The material deposited on the tunnel wall is attributed to the dust resuspension generated by air turbulence inside the tunnels (Pant and Harrison, 2013). As mentioned, $\mathrm{SO}_{2}$ is a pollutant gas emitted by vehicles and causes acid rain. In fact, the calcium sulfate (gypsum) can be formed by dry deposition of $\mathrm{SO}_{2}$ on rock interacting with air humidity, and by absorption of $\mathrm{SO}_{2}$ in liquid aerosol or by wet deposition forming $\mathrm{H}_{2} \mathrm{SO}_{4}$ that can dissolve $\mathrm{CaCO}_{3}$ (Olaru et al., 2010). Additionally, the presence of sulfates can also be attributed to the disseminated calcite-pyrite-epidote relationship in the mineralogical conformation of the tunnels (García Dobarganes and Barabas, 1997).

\section{CONCLUSIONS}

We monitored the $\mathrm{CO}, \mathrm{PM}_{2.5}$, and $\mathrm{PM}_{10}$ concentrations inside three road tunnels, viz., Los Ángeles, Galereña, and Barretero, within the city of Guanajuato to assess the air quality. The tunnels exhibited average CO concentrations (25,34, and 29 ppm for LA, GA, and BA, respectively) below the WHO's guideline for a 30-minute exposure $(50 \mathrm{ppm})$. However, the average PM10 concentrations $\left(95,108\right.$, and $93 \mu \mathrm{g} \mathrm{m}^{-3}$ for LA, GA, and BA, respectively) failed to meet the guideline for a 24-hour exposure $\left(50 \mu \mathrm{g} \mathrm{m}^{-3}\right)$. These results confirm poor air quality inside the tunnels, which can cause health issues for pedestrians or drivers who frequently traverse them.

The average EFs that we calculated for the average concentration of $\mathrm{CO}$ fell within the recommended limits, but those for the $\mathrm{PM}_{2.5}$ and $\mathrm{PM}_{10}$ significantly exceeded the values reported in other studies. Thus, these tunnels require artificial ventilation systems to mitigate the heavy pollution and ensure good air quality.

The concentrations of the investigated pollutants varied within the tunnels and increased toward the exits. This phenomenon was primarily due to the piston effect and the tunnels' natural ventilation, which generated drag in the direction of the vehicular flow. Furthermore, we found no clear correlation was observed between the levels of the $\mathrm{CO}$ and PM, indicating differences in the sources of these pollutants, namely, vehicular exhaust tire wear, brake pad wear, road erosion, and dust resuspension in addition to vehicular exhaust emission for the latter. The elemental composition of the PM, which we analyzed via SEM, XRD, and XRF, revealed its common origin with the particles deposited on the tunnel resuspended dust. Finally, the permissible length of naturally ventilated tunnels must be considered in implementing a ventilation system, especially for PM.

\section{ACKNOWLEDGMENTS}

This work was funded by the University of Guanajuato, supported by the Laboratory of Research and Characterization of Minerals and Materials (LICAMM). We acknowledge the critical comments from anonymous reviewers and editor.

\section{REFERENCES}

Anenberg, S., Miller, J., Injares, R., Du, L., Henze, D., Lacey, F., Malley, C.S., Emberson, L., Franco, V., Klimont, Z., Heyes, C. (2017). Impacts and mitigation of excess diesel-related $\mathrm{NO}_{\mathrm{x}}$ emissions in 11 major vehicle markets. Nature 545, 467-467. https://doi.org/10.1038/nature22086

Blanco, M., Parra, A., Ruiz, M.E. (2011). Breve historia de Guanajuato, 3ra. Ed. Fondo de Cultura Económica, México. https://issuu.com/guadalupelondon/docs/historia_de_guanaj uato_d842b3f5956f7f

Bleecker, M.L. (2015). Chapter 12 - Carbon monoxide intoxication, in: Lotti, M., Bleecker, M.L. (Eds.), Handbook of Clinical Neurology, Elsevier, pp. 191-203. https://doi.org/10.1016/B9780-444-62627-1.00024-X

Borghi, F., Spinazzè, A., Campagnolo, D. Rovelli, S., Cattaneo, A., Cavallo, D.M. (2018). Precision 
and accuracy of a direct-reading miniaturized monitor in $\mathrm{PM}_{2.5}$ exposure assessment. Sensors 18, 3089. https://doi.org/10.3390/s18093089

Brimblecombe, P., Townsend, T., Lau, C.F., Rakowska, A., Chan, T.L., Mocnik, G., Ning, Z. (2015). Through-tunnel estimates of vehicle fleet emission factors. Atmos. Environ. 123, 180-189. https://doi.org/10.1016/j.atmosenv.2015.10.086

Brugge, D., Durant, J.L., Rioux, C. (2007). Near-highway pollutants in motor vehicle exhaust: A review of epidemiologic evidence of cardiac and pulmonary health risks. Environ. Health 6, 23. https://doi.org/10.1186/1476-069X-6-23

Calla, D.L., Luján, P.M. (2018). Mobile source emissions inventory with a spatial and temporal distribution for the metropolitan area of Cochabamba, Bolivia. Acta Nova. 8, 322-353. http://www.revistasbolivianas.org.bo/scielo.php?script=sci_arttext\&pid=S1683-0789201800 0100005\&lng=en\&nrm=iso\&tlng=es

Carreón, M.C. (2007). Desastre en Guanajuato: la inundación del 5 de julio de 1760. Tzintzun. Revista de Estudios Históricos. 45, 11-32. https://www.redalyc.org/articulo.oa?id=89804502

Cui, M., Chen, Y., Tian, C., Zhang, F., Yan, C., Zheng, M. (2016). Chemical composition of PM2.5 from two tunnels with different vehicular. Sci. Total Environ. 550, 123-132. https://doi.org/10. 1016/j.scitotenv.2016.01.077

Diharja, R., Rivai, M., Mujiono, T., Pirngadi, H. (2019). Carbon Monoxide Sensor Based on NonDispersive Infrared Principle. J. Phys.: Conf. Ser. 1201, 012012. https://doi.org/10.1088/1742 6596/1201/1/012012

Dong, J., Tao, Y., Xiao, Y., Tu, J. (2017). Numerical simulation of pollutant dispersion in urban roadway tunnels. J. Comput. Multiph. Flows 9, 26-31. https://doi.org/10.1177/1757482X176 94041

El Salam, M.E.A. (2002). Construction of underground works and tunnels in ancient Egypt. Tunnelling Underground Space Technol. 17, 295-304. https://doi.org/10.1016/S0886-7798(0 2)00025-1

EL-Kassaby, M., Eldrainy, Y., Khidr, M., Khidr, K. (2016). Effect of hydroxy (HHO) gas addition on gasolina engine performance and emissions. J. Alex. Eng. 55, 243-251.

Fazlzadeh, M., Rostami, R., Hazrati, S., Rastgu, A. (2015). Concentrations of carbon monoxide in indoor and outdoor air of Ghalyun cafes. Atmos. Pollut. Res. 6, 550-555. https://doi.org/10.5 094/APR.2015.061

Ferm, M., Sjöberg, K. (2015). Concentrations and emission factors for $\mathrm{PM}_{2.5}$ and $\mathrm{PM}_{10}$ from road traffic in Sweden. Atmos. Environ. 119, 211-219. https://doi.org/10.1016/j.atmosenv.2015.0 8.037

Franco, V., Kousoulidou, M., Muntean, M., Ntziachristos, L., Hausberger, S., Dilara, P. (2013). Road vehicle emission factors development: A review. Atmos. Environ. 70, 84-97. https://doi.org/10.1016/j.atmosenv.2013.01.006

García Dobarganes, J., Barabas, A. (1997). Significado de concentraciones anómalas de sulfatos en análisis de agua para estudios de contaminación y la prospeccion regional. Ejemplo: El distrito minero de Guanajuato: Asociación de Ingenieros de Minas, Metalurgistas y Geólogos de México, A.C, GEOMIMET, XXIV, 2017, 17-22.

Gillies, J.A., Gertler, A.W., Sagebiel, J.C., Dippel, W.A. (2001). On-road particulate matter $\left(\mathrm{PM}_{2.5}\right.$ and $\mathrm{PM}_{10}$ ) emissions in the sepulveda tunnel, Los Angeles, California. Environ. Sci. Technol. 35, 1054-1063. https://doi.org/10.1021/es991320p

Grivas, G., Cheristanidis, S., Chaloulakou, A. (2012). Elemental and organic carbon in the urban environment of Athens. Seasonal and diurnal variations and estimates of secondary organic carbon. Sci. Total Environ. 414, 535-545. https://doi.org/10.1016/j.scitotenv.2011.10.058

Gustafsson, M., Johansson, C. (2012). Road Pavements and PM10. Trafikverket Report. 241.

Hacar, F., Jönsson, J., Vigne, G. (2016). Contaminantes del aire en los túneles de carretera y límites admisibles, de RADI. 7.

Hall, D., Anderson, D., Martin, C., Ren, X., Salawitch, R., He, H., Canty, T., Hains, J., Dickerson, R. (2020). Using near-road observations of $\mathrm{CO}, \mathrm{NO}_{y}$, and $\mathrm{CO}_{2}$ to investigate emissions from vehicles: Evidence for an impact of ambient temperature and specific humidity. Atmos. Environ. 232, 117558. https://doi.org/10.1016/j.atmosenv.2020.117558

Handler, M., Puls, C., Zbiral, J., Marr, I., Puxbaum, H., Limbeck, A. (2008). Size and composition of particulate emissions from motor vehicles in the Kaisermuhlen-Tunnel, Vienna. Atmos. 
Environ. 42, 2173-2186. https://doi.org/10.1016/j.atmosenv.2007.11.054

Hun, C.P. (2016). Manual de diseño y construcción de túneles de carretera. https://www. sct.gob.mx/fileadmin/DireccionesGrales/DGST/Manuales/Manual_Tuneles/Indice.pdf

Instituto Nacional de Estadística, Geografía e Informática (INEGI) (2015). https://www.inegi.o rg.mx/sistemas/olap/consulta/general_ver4/MDXQueryDatos.asp?proy=

Jing, B.Y., Wu, L., Mao, H.J., Gong, S.L., He, J.J., Zou, C., Song, G.H., Li, X.Y., Wu, Z. (2016). Development of a vehicle emission inventory with high temporal-spatial resolution based on NRT traffic data and its impact on air pollution in Beijing - Part 1: Development and evaluation of vehicle emission inventory. Atmos. Chem. Phys. 15, 19239-19273. https://doi.org/10.5194/ acp-16-3161-2016

Kojima, M., Futose, T., Binh, P.L., Kato, H. (2015). Yangon's urban transportation: Traffic demand and its quality of service. J. East Asia Soc. Transp. Stud. 11, 243-262. https://doi.org/10.11175/ easts.11.243

Lepe, J., Loza, A. (2016) Comparación de las características del conglomerado Guanajuato con el grupo Balsas en el área de Taxco de Alarcón Guerrero, México. Tlamati Sabiduría, 7, 1-12. http://tlamati.uagro.mx/t7e2/603.pdf

Li, Q., Chen, C., Deng, Y., Li, J., Xie G., Li, Y., Hu, Q. (2015). Influence of traffic force on pollutant dispersion of $\mathrm{CO}, \mathrm{NO}$ and particle matter $\left(\mathrm{PM}_{2.5}\right)$ measured in an urban tunnel in Changsha, China. Tunnelling Underground Space Technol. 49, 400-407. https://doi.org/10.1016/j.tust.20 15.04.019

Li, Z., Che, W., Frey, H.C., Lau, A.K.H., Lin, C. (2017). Characterization of PM2.5 exposure concentration in transport microenvironments using portable monitors. Environ. Pollut. 228, 433-442. https://doi.org/10.1016/j.envpol.2017.05.039

Liu, N.M., Grigg, J. (2018). Diesel, children and respiratory disease. BMJ Paediatr Open 2, e000210. https://doi.org/10.1136/bmjpo-2017-000210

Longley, I., Coulson, G., Olivares, G. (2010). Guidance for the Management of Air Quality in Road Tunnels in New Zealand. NIWA Research Report for NZ Transport Agency. NIWA Report AKL2010-045. https://www.nzta.govt.nz/assets/resources/air-quality-monitoring/docs/air-qualitytunnels-guidance.pdf

Ma, C.M., Hong, G.B., Chang, C.T. (2011). Influence of traffic flow patterns on air quality inside the longest tunnel in Asia. Aerosol Air Qual. Res. 11, 44-50. https://doi.org/10.4209/aaqr.201 0.09.0078

McNabola, A., McCreddin, A., Laurence, W.G., Broderick, B.M. (2011). Analysis of the relationship between urban background air pollution concentrations and the personal exposure of office workers in Dublin, Ireland, using baseline separation techniques. Atmos. Pollut. Res. 2, 80-88. https://doi.org/10.5094/APR.2011.010

Met One Instruments, Inc. (2020). Grants Pass, Oregon 97526-1052, USA.

Nagendra, R., Sohana, D., Harish, P. (2021). Development of real-world emission factors for on-road vehicles from motorway tunnel measurements. Atmos. Environ. 10, 100113. https://doi.org/10.1016/j.aeaoa.2021.100113

Olaru, M., Aflori, M., Simionescu, B, Doroftei, F., Stratulat, L. (2010). Effect of $\mathrm{SO}_{2}$ dry deposition on porous dolomitic limestones. Materials 3, 216-231. https://doi.org/10.3390/ma3010216

Pant, P., Harrison, R.M. (2013). Estimation of the contribution of road traffic emissions to particulate matter concentrations from field measurements: a review. Atmos. Environ. 77, 7897. https://doi.org/10.1016/j.atmosenv.2013.04.028

Park, M., Joo, H.S., Lee, K., Jang, M., Kim, S.D., Kim, I., Borlaza, L.J.S., Lim, H., Shin, H., Chung, K.H., Choi, Y.H., Park, S.G., Bae, M.S., Lee, J., Song, H., Park, K. (2018). Differential toxicities of fine particulate matters from various sources. Sci. Rep. 8, 17007. https://doi.org/10.1038/s41598018-35398-0

Pérez, P.J., Miranda, R.M., Nogueira, T., Guardani, M.L., Fornaro, A., Ynoue, R., Andrade, M.F. (2014). Emission factors of air pollutants from vehicles measured inside road tunnels in São Paulo: Case study comparison. Int. J. Environ. Sci. Technol. 11, 2155-2168. https://doi.org/10. 1007/s13762-014-0562-7

Permanent International Association of Road Congresses (PIARC) (2004). Technical Committee on Road Tunnels, "Road tunnels: Vehicle emissions and air demand for ventilation", reference 05.14.B, Paris. 
Permanent International Association of Road Congresses (PIARC) (2019). Road Tunnels: Vehicle Emissions and Air Demand for Ventilation. PIARC World Road Association. Paris, France, 2019. http://www.piarc.org

Priego, D.E. (2010). Túneles y Tuneladoras. 1st ed. Limusa, México.

Puy, M.J., Reyes, V., Wrobel, K., Wrobel, K., Torres, J.C., Miranda, R. (2016). Polycyclic aromatic hydrocarbons in urban tunnels of Guanajuato city (Mexico) measured in deposited dust particles and in transplanted lichen Xanthoparmelia mexicana (Gyeln.) Hale. Environ. Sci. Pollut. Res. 23, 11947-11956. https://doi.org/10.1007/s11356-016-6256-6

Sanchez-Ccoyllo, O.R., Ynoue, R.Y., Martins, L.D., Astolfo, R., Miranda, R.M., Freitas, E.D., Borges, A.S., Fornaro, A., Freitas, H., Moreira, A., Andrade, M.F. (2009). Vehicular particulate matter emissions in road tunnels in Sao Paulo, Brazil. Environ Monit Assess. 149, 241-249. https://doi.org/10.1007/s10661-008-0198-5

Satsangi, P.G., Yadav, S. (2014). Characterization of $\mathrm{PM}_{2.5}$ by X-ray diffraction and scanning electron microscopy-energy dispersive spectrometer: Its relation with different pollution sources. Int. J. Environ. Sci. Technol. 11, 217-232. https://doi.org/10.1007/s13762-012-0173-0

Sawyer, R.F., Harley, R.A., Cadle, S.H., Norbeck, J.M., Slott, R., Bravo, H.A. (2000). Mobile sources critical review: 1998 NARSTO assessment. Atmos. Environ. 34, 2161-2181. https://doi.org/10. 1016/S1352-2310(99)00463-X

Šulc, J., Ferkl, L., Cigler, J., Pořízek, J. (2017). Optimization-based control of ventilation in a road tunnel complex. Control Eng. Pract. 69, 141-155. https://doi.org/10.1016/j.conengprac.2017. 09.011

Tan, X., Zhang, H., Li, J., Wan, H., Guo, Q., Zhu, H., Liu, H., Yi, F. (2020). Non-dispersive infrared multi-gas sensing via nanoantenna integrated narrowband detectors. Nat. Commun. 11, 5245. https://doi.org/10.1038/s41467-020-19085-1

The National Institute for Occupational Safety and Health (NIOSH) (2020). https://search.cd c.gov/search/index.html?query=CO\&sitelimit=NIOSH\&utf8=\%E2\%9C\%93\&affiliate=cdc-main

Timmers, V.R.J.H., Achten, P.A.J. (2016). Non-exhaust PM emissions from electric vehicles. Atmos Environ. 134, 10-17. https://doi.org/10.1016/j.atmosenv.2016.03.017

United States Environmental Protection Agency (U.S. EPA) (2021). https://www.epa.gov/criteriaair-pollutants/naaqs-table

Wang, J.J., Zhao, L.J., Zhu, D.L., Gao, H.O., Xie, Y.J., Li, H.Y., Xu, X., Wang, H.B. (2016). Characteristics of particulate matter (PM) concentrations influenced by piston wind and train door opening in the Shanghai subway system. Transp. Res. D. Transp. Environ. 47, 77-88. https://doi.org/10.1016/j.trd.2016.05.006

Wang, X., Li, M., Peng, B. (2018). A Study on vehicle emission factor correction based on fuel consumption measurement. IOP Conf. Ser. Earth Environ. Sci. 108, 042049. https://iopscience. iop.org/article/10.1088/1755-1315/108/4/042049

Woitrin-Bibot, E., Martínez-Arredondo, J.C., Ramos-Arroyo, Y.R. (2015). Crecimiento urbano e incremento de riesgos hidrológicos en la ciudad de Guanajuato, México. L'Ordinaire des Amériques. https://doi.org/10.4000/orda.1937

World Health Organization (WHO) (2010). Air Quality Guidelines for Europe, Bonn Office. https://apps.who.int/iris/handle/10665/260127

Zeb, B., Alam, K., Sorooshian, A., Blaschke, T., Ahmad, I., Shahid, I. (2018). On the morphology and composition of particulate matter in an urban environment. Aerosol Air Qual. Res. 18, 1431-1447. https://doi.org/10.4209/aaqr.2017.09.0340

Zhao, D., Chen, H., Li, X., Ma, X. (2018a). Air pollution and its influential factors in China's hot spots. J. Cleaner Prod. 185, 619-627. https://doi.org/10.1016/j.jclepro.2018.02.181

Zhao, D.T, Chen, H., Shao, H.P., Sun, X. (2018b). Vehicle emission factors for particulate and gaseous pollutants in an urban tunnel in Xi'an, China. J. Chem. 2018, 8964852. https://doi.org/ $10.1155 / 2018 / 8964852$

Zhou, R., Wang, S., Shi, C., Wang, W., Zhao, H., Liu, R., Chen, L., Zhou, B. (2014). Study on the Traffic Air Pollution inside and outside a Road Tunnel in Shanghai, China. PLoS One 9, e112195. https://doi.org/10.1371/journal.pone.0112195 